\title{
UTILIZING OF DARK MEAT TUNA FISH (ThUnnUs sp. ) AND TRASH FISH SURIMI IN THE PROCESSING OF FISH BURGER
}

\author{
Fredy Pattipeilohy') and Angcivioletta Moniharapon'2) \\ 1)Department of Fish Processing Technology Faculty of Fisheries and Marine Science, \\ Pattmura University, Ambon, Indonesia \\ 2) Peneliti Baristand Manado, Indonesia
}

\begin{abstract}
Trash fish as by-catch includes a wide variety of species caught in shrimp fishing and usually is under utilizied while produced in a great number. Weakness of trash fish are small in measure with bone system, big husk and scale which resulting amount of yield flesh to be utilized relative small. So that, in processing a product require addition of order fish flesh. The objectives of this research were to study the amount of yield of minced fish that can utilizied for fish burger, quality and calory value of the product, and the level of panelists acceptance. Fish burger made from trash fish, used 2 (two) species as gulamah / Silver Pennah Croaker (Argyrosomus amoyensis), senangin / Fourfinger Threadfin (Elentheroma tetradactylum), and dark meat of Tuna (Thunnus sp). Minced fish of these two species was mixed with tuna flesh by ratio 1:1 (gulamah tuna) (A1), 1:2 (senangin tuna) (A2), 1:3 (gulamah tuna) (A3), 1:4 (senangin tuna) (A4), trash minced fish (gulamah senangin) (A5) and dark meat tuna minced fish (A6) as control. Research design applied was Complete Randomized Design with 4 replications. The result showed that amount of yield of minced fish are $47.8 \%$ gulamah), $33.9 \%$ (senangin) and $4.4 \%$ (dark meat of tuna). The quality of fish burger products water content 46.00-53.93 $\%$, protein content $12.78-20.84 \%$, fat content $12.83-19.52 \%$, ash content $2.32-3.33 \%$, and carbohydrate content 11.61-17.36\% (by-difference). Calory value 253.8-286.9 kcal. Sensory/orgaoleptic test value of this product is 7,04. - 7,93 (aspire). Treatment of minced of gulamah mixed with tuna 1:3 (A3), the fish burger with the best quality as it was by indicated by the water content $50.22 \%$, protein content $20.84 \%$ and fat content $12.83 \%$.
\end{abstract}

Key words : Dark meat tuna, trash fish, minced fish, amount of yield, fish burger

\section{INTRODUCTION}

According to Suparno and Dwiponggo (1993) by-catch in shrimp fishing consist of small pelagis and other species which is under utilizied. Source of fish under utilized which have the biggest potency were trash fish, which consist of various type of demersal and some of small pelagis. Weakness of trash fish are small in measure with bone system, big husk and scale which resulting amount of yield flesh to be utilized relative small. So that, in processing a product require addition of order fish flesh.

Trash fish is the mix of varions types of fish resulted from trawler and has a chemical composition which is equal to other fish, but fat and ash content is lower than $2 \%$ (Nasran and Tambunan, 1974). Setiabudi et al, ( 1984) showed that fish raw material of trash fish before getting any treatment contain $76.12 \%$ water, $12.14 \%$ protein and $1.39 \%$ fat content. Trash fish which one has white meat and it is good for making fish jelly products like fish ball, and sausage of surimi (Tan et al., 1987). 
In Indonesia exploiting of trash fish as raw material for making commercial food products is still less.Commonly, those of trash fish sold cheaply while others my be aried. The aim of the research was to know the fish flesh that can be exploited to become fish burger, the percentage of product of raw material weight, quality and calculation of the return of processing of burger.

\section{MATERIALS AND METHODS}

\section{Materials}

Fish flesh trash fish, used 2 (two) species as gulamah / Silver Pennah Croaker (Argyrosomus amoyensis), senangin / Fourfinger Threadfin (Elentheroma tetradactylum), and dark meat of Tuna (Thunnus sp), Smooth salt, butter, chiken egg flour of tapioka $8 \%$,sugar $2 \%$, shallot $1.5 \%$, garlic $0.3 \%$, ginger $0.1 \%$, merica $0.8 \%$, flavour (mono sodium glutamate) $0.25 \%$, bayleaf sufficiently. Knife, talenan cooking board, bowl, balance, tablespoon, blender, mixer, tray, cling wrap, burger aluminium mould size 28 .

\section{Preparation of ingredient and materials}

Shallot, ginger and garlic with comparison $15: 3: 1$, blended until smooth (condiment). Bay leave into small pieces. Flour of tapioka, butter, salt, sugar, and peppercorn of condiment weight ed and processed.

\section{Preparation of flesh or minced fish}

Various of fresh fish type with the best quality washed, cleaned and removed scales. Filleted and Chilling. Remaining off flesh on the bone tuhen out by sloon and attach to the fillet. Fish Fillet and fish flesh cleaned and pressed 2 times. The minced fish ready to be processed become fish burger, and at the same time await to next step.

\section{Dough Preparation}

Addition of salt $2.5 \%$ into minced, stired untill wel mixed. Addition of butter into minced fish, stir untill wel mixed. Addition of egg (1) to every $1 \mathrm{~kg}$ minced fish. Addition of flour of tapioka bit by bit as much as $8 \%$. Sequentially add sugar, condiment, peppercorn and other ingredient into that mixture.

\section{Forming and Freezing}

Preparation of sheet of thin plastic $40 \times 25 \mathrm{~cm}$, then invested by a few/little butter. This plastic was used as a barrier between dough and packaging. so that dough do not come into contact with can. Put dough into forming mould which have been arised with butter, each can $400 \mathrm{~g}$. Folding sheet of plastic to wrap the dough into printing mould. Removing dough which have been prepacked into other printing mould with shares of plastic folded underside at that printing mould. Freeze the dough temperature $-25{ }^{\circ} \mathrm{C}$ for $8-10$ hours 


\section{Presentation}

Freeze Fish Burger cutted to pieces with $1.5 \mathrm{~cm}$ according to the wide of printing mould, divided into two according to printing mould cutting length, of $9 \times 2 \times 1.5 \mathrm{~cm}$. Fish burger cut deep into egg yolk agitation, and then applied flour of dry bread powder. Frying in oil with moderate flame. Fried Burger to be served and assessed by acceptance level of panelist. Scheme of Processing of Fish Burger was described Figure 1.

\section{In each processing of fish burger conducted}

Measuring the weight of fish used. Measuring the weight of minced fish that could be used as fish burger. Measuring the weight of minced fish of each species according to the treatment applied. Measuring the weight of the fish burger resulted from each treatment.

\section{Parameter Analysed}

Quality Analysis consist of objective parameter i.e.: water content, protein content, fat content, ash content, carbohydrate and calory / energy value and subjective parameter: acceptance, smell, flavor and texture by using Hedonic scale of 1 to 9 .

\section{Treatments}

Fish burger made from trash fish, used 2 (two) species as gulamah / Silver Pennah Croaker (Argyrosomus amoyensis), senangin / Fourfinger Threadfin (Elentheroma tetradactylum), and dark meat of Tuna (Thunnus sp). Based on the availability of fish, hence treatment the designed as follows: Comparison of dark meat of tuna with fish flesh of gulamah $1: 1$ (A1), Comparison of dark meat of tuna with fish flesh of senangin $2: 1$ (A2), Comparison of dark meat of tuna with fish flesh of gulamah $3: 1$ (A3), Comparison of dark meat of tuna with fish flesh of senangin $4: 1$ (A4), Flesh Fish of gulamah and senangin (1:!) as control (A5), Dark meat of tuna as control (A6). 


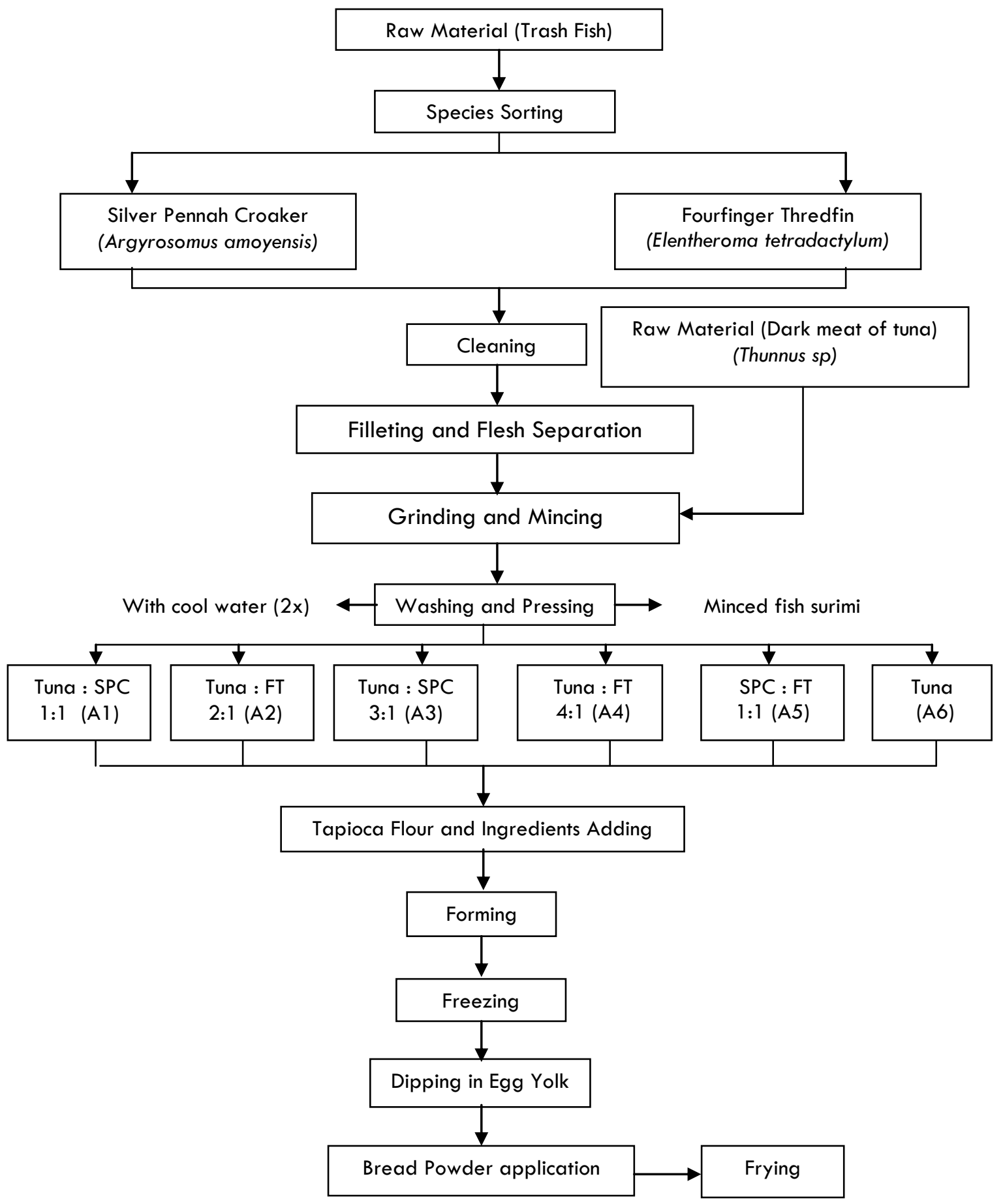

Figure 1. Scheme of Processing of Fish Burger

\section{Data Analysis}

The objective parameters were analyzed by Complete Randomized Design with four replications and followed by Honest Significant Difference (HSD) (Gaspersz, 1994). While the subjective parameters were analyzed by Friedman test and followed by Multiple Comparison (Wayne, 1989). 


\section{RESULTS AND DISCUSSION}

\section{Yield}

The amount of minced fish that could be used as fish burger after passing wash process and press (minced fish) can be seen at Table 1.

Table 1. The Yield of minced Flesh used as Fish Burger.

\begin{tabular}{cccc}
\hline Species & Fish Weight $(\mathrm{g})$ & $\begin{array}{c}\text { Minced Fish } \\
\text { Weight }(\mathrm{g})\end{array}$ & Yield (\%) \\
\hline Silver Pennah & 4,520 & 2,180 & 48.2 \\
Croaker & 4,340 & 2,060 & 47.5 \\
& 4,440 & 2,140 & 47.8 \\
\hline Average & 4,430 & 2,120 & 47.8 \\
\hline \multirow{2}{*}{ Fourfinger } & 2,560 & 850 & 33.2 \\
Threadfin & 2,700 & 940 & 34.8 \\
& 2,620 & 880 & 33.6 \\
\hline Average & 2,630 & 890 & 33.9 \\
\hline \multirow{2}{*}{ Tuna } & $6.500(700)$ & 290 & 4.5 \\
& $8.800(900)$ & 370 & 4.2 \\
Average & $11,200(1,200)$ & 490 & 4.4 \\
\hline
\end{tabular}

Amount of minced fish resulted from each of fish type was as follow silver pennah croaker is more than $4 \mathrm{~kg}$ equal to $47.8 \%$ (average $192 \mathrm{~g} /$ tail); fourfinger threadfin more than $2.5 \mathrm{~kg}$ equal to $33.9 \%$ (average $105 \mathrm{~g} /$ tail); tuna in more or less $10 \mathrm{~kg}$ equal to 4.4 $\%$ (average 8,830.3 g / tail). Thereby yield flesh fish amount was in line with ever greater of fish weight and measure. Silver pennah croaker in form of ellipse, wide and long; fourfinger threadfin in the form of ellipse, not wide, not length and big head. Suzuki ( 1981) expressed that yield of flesh fish vary depend on fish type, fish measure, body form, of old age and arrest season. Generally yield of flesh fish between $45-50 \%$. The yield of flesh fish in the form of ellipse about $60 \%$, and fish which big head 35 - $45 \%$. Pattipeilohy ( 2004) reported that yield of flesh fish of silver pennah croaker equal to $46.7 \%$ ( heavy rate $175 \mathrm{~g} /$ tail) and fourfinger threadfin $33.0 \%$ ( heavy rate $90 \mathrm{~g} /$ tail), which is dissociation of flesh with flesh separator used of form of filet so that do not remain flesh at husk followed isn't it flesh of bone. Huda ( 1994) reported yield flesh fish fourfenger threadfin equal to $32 \%$ (heavy rate $45 \mathrm{~g} /$ tail) which is dissociation of flesh.

\section{Quality of Fish Burger}

Objective parameter of quality of fish burger perceived cover: water, protein, fat, ash, carbohydrate content analysis and calory value, while subjective parameter is sensory test as follows: acceptance, smell/aroma, flavor and texture level.

\section{Objective Parameter}

Recapitultion of varians analysis and Honest Significant Difference (HSD) showed at Table 2. 
Table 2. Recapitulation Varians Analysis and Honest Significant Difference (HSD) Objective Parameters Fish Burger

\begin{tabular}{cllllll}
\hline Treatment & $\begin{array}{c}\text { Water } \\
(\%)\end{array}$ & $\begin{array}{c}\text { Protein } \\
(\%)\end{array}$ & $\begin{array}{c}\text { Fat } \\
(\%)\end{array}$ & $\begin{array}{c}\text { Ash } \\
(\%)\end{array}$ & $\begin{array}{c}\text { Carbohydrate } \\
(\%)\end{array}$ & $\begin{array}{c}\text { Calory } \\
\text { Value } \\
(\text { kcal) }\end{array}$ \\
\hline A1 & $49.88^{\mathrm{b}}$ & $16.19^{\mathrm{c}}$ & $\mathbf{1 9 . 5 2 \mathrm { a }}$ & $2.80^{\mathrm{ab}}$ & $\mathbf{1 1 . 6 1}$ & $\mathbf{2 8 6 . 9}$ \\
A2 & $\mathbf{4 6 . 0 0 ^ { \mathrm { c } }}$ & $17.24^{\mathrm{bc}}$ & $16.07^{\mathrm{b}}$ & $\mathbf{3 . 3 3}^{\mathrm{a}}$ & 17.36 & 283.0 \\
A3 & $50.21^{\mathrm{b}}$ & $\mathbf{2 0 . 8 4 ^ { \mathrm { a } }}$ & $\mathbf{1 2 . 8 3 ^ { \mathrm { c } }}$ & $2.63^{\mathrm{b}}$ & 13.49 & $\mathbf{2 5 3 . 8}$ \\
A4 & $48.15^{\mathrm{bc}}$ & $18.2^{\mathrm{b}}$ & $14.93^{\mathrm{bc}}$ & $2.38^{\mathrm{b}}$ & 11.82 & 256.5 \\
A5 & $\mathbf{5 3 . 9 3 ^ { \mathrm { a } }}$ & $\mathbf{1 2 . 7 8 ^ { \mathrm { d } }}$ & $16.08^{\mathrm{b}}$ & $2.39^{\mathrm{b}}$ & 14.92 & 255.5 \\
A6 & $48.50^{\mathrm{bc}}$ & $16.40^{\mathrm{c}}$ & $15.67^{\mathrm{b}}$ & $\mathbf{2 . 3 2 ^ { \mathrm { b } }}$ & 17.11 & 275.0 \\
F Value & 12.88 & 62.35 & 68.00 & 8,33 & & \\
F Table & 2.77 & 2,77 & 2,77 & 2,77 & & \\
HSD & 3.32 & 1.53 & 2.47 & 0.60 & & \\
\hline
\end{tabular}

NB. Number followed by is same letter real on same column do not differ at level of 0.05 significant.

\section{Water Content}

The average of water content of fish burger was ranged from $46.00-53.93 \%$ (seeing Table 2). The highest was $53.93 \%$ on the treatment trash fish (gulamah and senangin) as control (A5), while the lowest was $46.00 \%$ on the treatment comparison of dark meat of tuna with fish flesh of senangin $2: 1$ (A2). The difference on fish species is known as the manner on the difference in the water content of the fish burger. Nasran and Tambunan (1974), report that fish chemical composition of silver pennah croaker is: water $79.27 \%$, protein $17.82 \%$, fat $1.73 \%$ and ash $0.01 \%$; fourfinger threadfin is: water $84.29 \%$, protein $15.43 \%$, fat $0.46 \%$ and ash content $0.77 \%$. Gaspersz and Pattipeilohy (2011), report that fish chemical of dark meat tuna is: water $79.50 \%$, protein $17.62 \%$, fat $1,41 \%$ and ash content $1.41 \%$.

The water content of the fish burger is lower than of the previous research by Arifudin (1993), from his research found the water content of fish burger was $58.2 \%$. Fish burger made from comparison of ikan kakap : tenggiri : cumi (squid) is $1: 5: 2$. The resource of the differentiation between this two results was predicated because of the different in fish species used in the two research and also because of the pressing treatment applied.

The difference was predicated because water content surimi after washing as reported by llyas, at al., (1988) water content fluctuation of pari (Trygon sephen) surimi after washing was $75,05-82,79 \%$. Before Grantham (1981) showed that difficult on water content minced fish control although with effective machine for pressing the water.

\section{Protein Content}

As a whole the quality of food product of fish was determined by content irrigate and prtein is two especial component. Rate irrigate product of fish very determine by rate irrigate early raw material. The average of protein content of fish burger was ranged from 12.78 $20.84 \%$ (seeing Table 2). The highest was $20.84 \%$ on the treatment comparison of dark meat of tuna with fish flesh of gulamah $3: 1$ (A3), while the lowest was $12.78 \%$ on the treatment flesh fish of gulamah and senangin $(1: 1)$ as control (A5). The difference of protein content was caused by difference of protein content of raw materials. Nasran and Tambunan (1974), 
report that fish chemical composition of silver pennah croaker is: water $79.27 \%$, protein $17.82 \%$, fat $1.73 \%$ and ash $0.01 \%$; fourfinger threadfin is: water $84.29 \%$, protein $15.43 \%$, fat $0.46 \%$ and ash content $0.77 \%$. Gaspersz and Pattipeilohy (2011), report that fish chemical of dark meat tuna is: water $79.50 \%$, protein $17.62 \%$, fat $1,41 \%$ and ash content $1.41 \%$. Winarno ( 1980), expressed that progressively lower rate water content product, hence protein content, fat, ash will be more excelsior. The protein content of the fish burger is consist than of the previous research by Arifudin (1993), from his research found the protein content of fish burger was $19.2 \%$.

\section{Fat Content}

The average of fat content of fish burger was ranged from $12.83-19.52 \%$ (seeing Table 2). The highest was $19.52 \%$ on the treatment comparison of dark meat of tuna with fish flesh of gulamah $1: 1$ (A1), while the lowest was $12.83 \%$ on the treatment comparison of dark meat of tuna with fish flesh of gulamah $3: 1$ (A3), The difference of fat content was caused by difference of fat content of raw materials. Winarno (1980), expressed that progressively lower rate water content product, hence protein content, fat, ash will be more excelsior. The fat content of the fish burger is higher than of the previous research by Arifudin (1993), from his research found the fat content of fish burger was $10.8 \%$.

\section{Ash Content}

The average of ash content of fish burger was ranged from 2.32-3.33\% (seeing Table 2). The highest was $3.33 \%$ on the treatment comparison of dark meat of tuna with fish flesh of senangin $2: 1$ (A2), while the lowest was $2.32 \%$ on the treatment dark meat of tuna as control (A6), The difference of fat content was caused by difference of fat content of raw materials. Winarno (1980), expressed that progressively lower rate water content product, hence protein content, fat, ash will be more excelsior. The ash content of the fish burger is consist than of the previous research by Arifudin (1993), from his research found the ash content of fish burger was $2,9 \%$.

\section{Carbohydrate Content}

The average of carbohydrate content (by-difference) of fish burger was ranged from $11.61-17.36 \%$ (seeing Table 2). The highest was $17.36 \%$ on the treatment comparison of dark meat of tuna with fish flesh of senangin 2:1 (A2), while the lowest was $11.61 \%$ on the treatment comparison of dark meat of tuna with fish flesh of gulamah $1: 1$ (A1), Winarno (1980), expressed that progressively lower rate water content product, hence protein content, fat, ash will be more excelsior. The carbohydrate content of the fish burger is higher than of the previous research by Arifudin (1993), from his research found the water conrent of fish burger was $8.3 \%$.

\section{Calory Value}

The average of calory value of fish burger was ranged from 253.8-286.9 kcal. (seeing Table 2). The highest was $286.9 \mathrm{kcal}$ on the treatment comparison of dark meat of tuna with fish flesh of gulamah 1:1 (A1), while the lowest was $253.8 \mathrm{kcal}$ on the treatment comparison 
of dark meat of tuna with fish flesh of gulamah $3: 1$ (A3). The difference of calory value was caused by difference of protein, fat and carbohydrate content of the products. According to Auliana (2001), calory or energy value of the food substance can be determined by using Atwater factor, in which each gram of lipid/fat, carbohydrate and protein equel to 9 cal, 4 cal and 4 cal, respectively.

\section{Subjective Parameter}

Recapitulation of Friedmen test and Multiple Comparision of sensory test value can be seen at Table 3.

Table 3. Recapitulation of Friedman test and Multiple Comparsion of Sensory Test Value

\begin{tabular}{|c|c|c|c|c|c|c|c|c|}
\hline Treament & $\begin{array}{l}\text { Averag } \\
\text { e of } A \\
V\end{array}$ & $\begin{array}{l}\text { Total } \\
\text { Ranking }\end{array}$ & $\begin{array}{l}\text { Averag } \\
\text { e of } S \\
V\end{array}$ & $\begin{array}{l}\text { Total } \\
\text { Ranking }\end{array}$ & $\begin{array}{l}\text { Averag } \\
\text { e of } F \\
V\end{array}$ & $\begin{array}{l}\text { Total } \\
\text { Ranking }\end{array}$ & $\begin{array}{l}\text { Averag } \\
\text { e of } T \\
V\end{array}$ & $\begin{array}{l}\text { Total } \\
\text { Ranking }\end{array}$ \\
\hline $\mathrm{A} 1$ & 7.85 & $15.0^{\mathrm{ab}}$ & 7.69 & $21.5^{a}$ & 7.38 & $6.0^{c}$ & 7.36 & $12.5^{c}$ \\
\hline A2 & 7.93 & $20.5^{a}$ & 7.44 & $13.5^{a b c}$ & 7.49 & $13.5^{a b c}$ & 7.43 & $17.0^{\mathrm{ab}}$ \\
\hline A3 & 7.39 & $5.0^{b}$ & 7.35 & $9.0 \mathrm{bc}$ & 7.64 & $16.0^{a b c}$ & 7.04 & $5.0^{c}$ \\
\hline A4 & 7.91 & $16.0^{a}$ & 7.22 & $5.0^{c}$ & 7.71 & $16.5^{\mathrm{ab}}$ & 7.93 & $22.0^{a}$ \\
\hline A5 & 7.63 & $13.5^{\mathrm{ab}}$ & 7.59 & $19.5^{a}$ & 7.44 & $9.5^{b c}$ & 7.57 & $16.0^{\mathrm{ab}}$ \\
\hline A6 & 7.66 & $14.0^{a b}$ & 7.66 & $15.5^{\mathrm{ab}}$ & 7.83 & $22.5^{a}$ & 7.34 & $11.5^{\mathrm{bc}}$ \\
\hline$X_{i 2}=$ & $S=11.1$ & $C V=10$ & $S=12.9$ & $C V=10$ & $S=12.6$ & $C V=10$ & $S=13.8$ & $C V=10$ \\
\hline 11.1 & & .4 & & .4 & & .4 & & .4 \\
\hline
\end{tabular}

NB. Number followed by is same letter real on same column do not differ at level of 0.05 significant.

The average of sensory test level at Table 2 (scale of hedonik 9) hence quality of fish burger 7.63 - 7.93 (appearance); 7.22 - 7.69 (smell); 7.38 - 7.83 (flavor) and $7.04-7.93$ (texture) or assessed to reside in level rather (7) aspire after ( 8 ); with product specification as follows: vision turn yellow chocolate, not muccous, natty surface; compact texture, elastic; specific smell of fish flesh and feel crispyly, and for flavour fish flesh and also flavour enough flavour.

Result test Friedman indicate that given treatment have an effect on reality to value appearance, smell, flavor and texture of fish burger. Result of Multiple Comparison test prove that value appearance fish burger treatment of better $A 2$, because yielding value of rate and amount of highest ranking that as 7.93 and 20.5 different reality to treatment of A3 (7.39 and 5.0). For the value smell treatment of better $A 1$, with 7.69 and 21.5 different reality to treatment of $A 3$ (7.35 and 9.0) and $A 4$ ( 7.22 and 5.0). For value flavor treatment of $A 6$ ( 7.83 and 22.5 ) differing reality to $A 5$ ( 7.44 and 9.5 ) and $A 1$ ( 7.38 and 6.0 ), but not differ reality to $A 2(7.49$ and 13.5 ), A3 ( 7.64 and 16.0 ) and $A 4(7.71$ and 16.5 ). For the value of texture treatment of $A 4$ ( 7.93 and 22.0 ) differing reality to $A 1$ ( 7.36 and 12.5 ), $A 6$ ( 7.34 and 11.5), and $A 3$ ( 7.04 and 5.0), but not differ reality to $A 2(7.43$ and 17.0 ), A5 ( 7.57 and 16.0 ).

As a whole assess acceptance level of panelist to the product of good enough fish burger (rather - aspire after). This prove that fish burger can use each fish flesh type and or mixture with a purpose to improve production. 
Sribhibhadh (1985) suggested that fleshly fish type turn white and fish type of demersal in general is good to made surimi, but fleshly fish squeeze and bream which although fleshly mean turn white is not good to made surimi. Grantham (1981) suggested that surimi is " intermediate processed of fish minced" (fall to pieces fish flesh as product among/between) used for making raw material, of various final product type which want forming gel ( elasticity). Miyake et al., (1985) expressed that surimi can be made by various fish type, so long as the fish have ability to form gel, flavor and good vision. Suzuki ( 1981) expressed that protein content of sarkoplasma of fish of demersal lower than the pelagic. Nature of this protein pursue forming of gel like kamaboko, and sausage of fish ball.

Discoloration on fish and fish product usually influenced by lipid oxidation and enzyme activities. Futhermore, Desrrosier (1977) showed that appearance or color of the product is main key in determining the quality of the product. Some of the discoloration commonly observed in frozen fish can probably be attributed to autolysis action, sugar produced by enzyme action can interact with the amino compuounds already present to produce brownish or yellowish compound (Huss, 1988).

The sources of smell or aroma on the fish and fish products are amino acid and fatty acids which are broken down from polypeptides and lipids respectively. The food aroma of the product caused the good taste of it. Aroma also has correlation of the taste of the product. Aroma is also known as one of quality indicator of the fish products (Clucas and Ward, 1996).

Flavor of the food is taken from the lipid composition in it, beside that addition of ingredient on the right composition will result the good taste. The characteristic sweet, meatly flavor of fresh fish at least partly due to compound called inosinic acid. The break down of of inosinic acid through autolysis results in a loss of this flavor. The present of ginger, garlic, mono sodium glutamate, spices and salt in the fish burger can build the good flavor of it.

Texture of the fish burger is affected by additive of salt to the minced fish while dough is made, so that the myosin in the salt soluble is separated from the fish flesh and to make sol that have adhesive carracteristics. This sol will change to be gel that build the elastics products (Tanikawa, 1971).

According to Fardiaz (1985), ability gel structure has correlation of the water bidding capacity and viscocity of the flour.

\section{CONCLUSION}

Amount of yield of minced fish are $47.8 \%$ gulamah), $33.9 \%$ (senangin) and $4.4 \%$ (dark meat of tuna). The quality of fish burger products water content 46.00-53.93\%, protein content 12.78- 20.84\%, fat content 12.83-19.52\%, ash content 2.32-3.33\%, and carbohydrate content 11.61-17.36\% (by-difference). Calory value 253.8-286.9 kcal. Sensory/orgaoleptic test value of this product is 7,04. - 7,93 (aspire). Treatment of minced of 
gulamah mixed with tuna 1:3 (A3), the fish burger with the best quality as it was by indicated by the water content $50.22 \%$, protein content $20.84 \%$ and fat content $12.83 \%$.

\section{REFERENCES}

Arifudin, R. 1993. Fish Stick dan Fish Burger. Di dalam kumpulan Hasil-Hasil Penelitian Pasca Panen Perikanan. Pusat Penelitian dan Pengembangan Perikanan. Badan Penelitian dan pengembangan Pertanian, Jakarta

Auliana, R., 2001. Gizi Dan Pengolahan Pangan. Adicita Karya Nusa.

Clucas I.J and A.R. Ward. 1996. Post-Harvest Fiheries Development: A Guide to Handling, Preservation, Processing and Quality, Cathham Maritime, Kent ME44TB, United Kingdom.

Desroiser, N.W. 1977. Teknologi Pengawetan Pangan. Penerjemah Mujoharto, M. Penerbit Universitas Indonesia. Jakarta.

Fardiaz, D. 1985. Kamaboko, Produk Olahan lkan yang Berpotensi Untuk Dikembangkan. Media Teknologi Pangan Vol. 1 (2) : $1-7$.

Gaspersz, V. 1994. Metode Perancangan Percobaan Untuk Ilmu-Ilmu Pertanian, IImu-Ilmu Teknik, dan Biologi. Penerbit Armico Bandung.

Gaspersz, F.F., dan F. Pattipeilohy. 2011. Pengembangan Teknologi Surimi dan Diversifikasi Produk Olahan dengan Memanfaatkan Limbah Produksi Tuna Loin. Laporan Laporan Penelitian Hibah Penelitian Strategi Nasional. Universitas Pattimura. Ambon.

Grantham, G.J. 1981. Minced Fish Technology: A Review. FAO of the United Nations. Rome

Huda, N. 1994. Pengolahan Daging Lumat Ikan Laut Berukuran Kecil Menjadi Berbagai Jenis Tepung Ikan: Evaluasi Nilai Gizi dan Sifat Fungsional Protein. Tesis Program Pascasarjana Institut Pertanian Bogor, Bogor.

Huss, H.H. 1988. Fresh Fish Quality and Quality Changes. FAO/DANIDA. Training Manual; Roma FAO of the United Nations.

llyas, S., S. Nasran dan H.E. Irianto. 1988. Penelitian Pendahuluan Pengolahan Daging Lumat Ikan Pari (Trygon sephan). Jurnal Penelitian Pasca Panen Perikanan No. $60: 39-46$.

Miyake, Y.,Y. Hirasawa and M. Miyanebe, 1985. Technology of Manufacturing. Info Fish Marketing Digest. 5: 29-32.

Nasran, S dan P.R. Tambunan, 1974. Penelitian Pendahuluan Pemanfaatan Trash Fish. Dalam Laporan Penelitian Teknologi Perikanan No.2/1974. Jakarta.

Pattipeilohy, F. 2004. Pengolahan Bakso Ikan dengan Memanfaatkan Ikan Rucah. Makalah disampaikan pada Seminar Nasional dan Kongres PATPI 2004, 17 - 18 Desember 2004, di Jakarta.

Setiabudi, E,. S. Bustaman dan D. Suryanto. 1984. Pemanfaatan Ikan Rucah dari Hasil Samping Pukat Jendela. LPTP No. 26/1984. Jakarta.

Sribhibhadh, A. 1985. Prospect in Developing on Production. In: Proceeding of the International Symposium on Engineered Seafood Including Surimi. R.E. Marthin (ed.). Collete R.L and National Fisheries Institute. Seattle. Washington DC.

Suparno dan A. Dwiponggo, 1993. Ikan-ikan yang Kurang Dimanfaatkan sebagai Bahan Bergizi Tinggi. Di dalam Prosiding Widyakarya Nasional Pangan dan Gizi V, 20 - 22 April 1993. LIPI Jakarta.

Suzuki T, 1981. Fish and Krill. Protein Processing Technology. Applied Science Publisher, Ltd. London.

Tanikawa, E. 1971. Marine Product In Japan. Technology and Research. Koseiha Koseikaku Company, Tokyo.

Tan Sen Min; Ng Mui Chung, T. Fujimara, Hooi Kok Kuang and H. Hasegawa. 1987. Hand Book on the Processing of Frozen Surimi and Fish Jelly Product in South East Asia. MFRD/SEAFDEC. Singapore.

Wayne, D.N. 1989. Statistik Non Parametrik. Penerjemah Alex W Kontjoro. Penerbit Universitas Indonesia. Jakarta.

Winarno. F.G. 1980, Kimia Pangan. PT. Gramedia. Jakarta. 